\title{
Reviewer Acknowledgements for Business and Management Studies, Vol. 7 , No. 4
}

Business and Management Studies (BMS) would like to acknowledge the following reviewers for their assistance with peer review of manuscripts for this issue. Many authors, regardless of whether BMS publishes their work, appreciate the helpful feedback provided by the reviewers. Their comments and suggestions were of great help to the authors in improving the quality of their papers. Each of the reviewers listed below returned at least one review for this issue.

\section{Reviewers for Volume 7, Number 4}

Abdul-Kahar Adam, University of Education, Winneba, Ghana

Dalia Susniene, Kaunas University of Technology, Lithuania

Iulia Cristina Muresan, University of Agricultural Sciences and Veterinary Medicine Cluj-Napoca, Romania

Iza Gigauri, St. Andrew the First-Called Georgian University, Georgia

Jayalakshmy Ramachandran, Multimedia University, Malaysia

Ellery Willianms

Editorial Assistant

On behalf of,

The Editorial Board of Business and Management Studies

Redfame Publishing

9450 SW Gemini Dr. \#99416

Beaverton, OR 97008, USA

URL: http://bms.redfame.com 